\title{
PENERAPAN METODE SIX SIGMA PADA PENGENDALIAN KUALITAS AIR KEMASAN DI PT. GUNUNG NAGA MAS
}

\author{
KARINA FORESTI, MAIYASTRI, YUDIANTRI ASDI \\ Jurusan Matematika, \\ Fakultas Matematika dan Ilmu Pengetahuan Alam, Universitas Andalas, \\ Kampus UNAND Limau Manis Padang, Indonesia, \\ email : karina_forestri@ymail.com
}

\begin{abstract}
Abstrak. PT. Gunung Naga Mas merupakan salah satu produsen air mineral kemasan lokal di Padang, dimana produk yang paling banyak diproduksi adalah air mineral kemasan cup $240 \mathrm{ml}$. Meningkatnya permintaan pasar berpengaruh terhadap kualitas produksi produk tersebut. Untuk melihat apakah produk tersebut sudah terkendali atau tidak, digunakan salah satu program peningkatan kualitas produk yaitu dengan menerapakan metode Six Sigma yaitu metode DMAIC. Penelitian ini bertujuan untuk mengidentifikasi masalah produksi, mengetahui faktor penyebab cacat, memperoleh solusi dalam upaya mengurangi jumlah cacat, mengetahui jenis cacat dan faktor cacat yang paling mendominasi pada produksi air mineral kemasan cup $240 \mathrm{ml}$ dan membuat bagan kendali untuk melihat hasil terkendali atau tidak. Karakteristik kualitas atau Critical to Quality (CTQ) untuk produksi air mineral kemasan cup $240 \mathrm{ml}$ ada 7 macam yaitu air kotor/berisi benda lain, air kurang dari volume pack, lid tidak presisi/timpang, cup pp bocor, cup pp bocor sealer, cup pp rijek pemasok, dan bocor jarum. DPMO dari cacat air mineral kemasan dalam penelitian diperoleh dari nilai rata-rata DPMO sebesar 26.547 dan rata-rata Sigma Level sebesar 3,49. Dari peta kendali $u$ disimpulkan bahwa hanya cacat bocor jarum yang berada dalam kendali statistik (terkendali) sedangkan cacat lainnya tidak terkendali.
\end{abstract}

Kata Kunci: Six Sigma, DMAIC, DPMO, Sigma Level

\section{Pendahuluan}

Dewasa ini kebutuhan masyarakat terhadap air mineral kemasan sangat tinggi. Ini dibuktikan dengan jumlah konsumen air mineral kemasan yang meningkat secara eksponensial dengan jumlah produksi air mineral kemasan satu tahun mencapai 26,90 miliar liter [3], sehingga lahir perusahaan-perusahaan industri yang bergerak di bidang air mineral kemasan dan menjadikan perkembangan pasar bisnis air mineral kemasan terus meningkat. Perusahaan sering kali mengalami cacat pada hasil produksi karena proses produksi dilakukan secara terus menerus untuk memenuhi permintaan pasar. Untuk mengurangi jumlah produk cacat dan mendapatkan kualitas produksi yang dapat bersaing, dibutuhkan metode pengendalian kualitas produk yang berkesinambungan. Pada penelitian ini akan digunakan metode Six Sigma karena berfokus pada minimalisasi cacat dan variasi. Dalam penelitian ini akan dilakukan analisis produk cacat pada produksi air mineral kemasan cup $240 \mathrm{ml}$ dengan menggunakan metode Six Sigma yaitu DMAIC. Penelitian ini dilaksanakan 
di perusahaan air minum swasta yaitu PT. Gunung Naga Mas di Padang.

\section{Data dan Metode Penelitian}

\subsection{Data}

Data yang digunakan pada penelitian ini adalah data atribut jumlah produk cacat yang merupakan data sekunder bersumber dari PT. Gunung Naga Mas, ada 26 pengamatan mulai tanggal 1 Maret 2017 sampai 31 Maret 2017. Data tersebut adalah data produksi air mineral kemasan cup $240 \mathrm{ml}$ yang diproduksi setiap hari kerja. Jenis cacat yang diteliti yaitu : air kotor/berisi benda lain, air kurang dari volume pack, lid tidak presisi/timpang, cup pp bocor, cup pp bocor sealer, cup pp rijek pemasok, dan bocor jarum.

\subsection{Metode Penelitian}

Penelitian ini menggunakan metode Six Sigma. Six Sigma pertama kali diperkenalkan oleh Motorola pada tahun 1987 oleh seorang Engineer yang bernama Bill Smith [2]. Six sigma adalah usaha yang dilakukan terus menerus bertujuan untuk menurunkan variasi dan mencegah cacat dari sebuah proses produksi dengan mengaplikasikan alat-alat statistik serta teknik untuk mereduksi cacat sampai didefinisikan tidak lebih dari 3 atau 4 cacat dari satu juta kesempatan untuk mencapai kepuasan pelanggan secara total [1].

Metode dalam Six Sigma adalah DMAIC yang merupakan singkatan dari Define (mendefinisikan), Measure (mengukur), Analyze (menganalisis), Improve (memperbaiki) dan Control (mengendalikan). Fase-fase dalam tahapan DMAIC sebagai berikut :

(1) Tahap Define

Define adalah langkah awal pada metode six sigma yaitu tahap untuk mengidentifikasi permasalahan yang terjadi, lalu mendefinisikan masalah tersebut dengan jelas.

(2) Tahap Measure

Pada tahap ini informasi atau data dikumpulkan untuk menentukan variabel kritis yang biasa disebut CTQ (Critical to Quality) yang berguna dalam pengukuran baseline kinerja. Dalam pengukuran baseline kinerja digunakan satuan pengukuran DPMO (Defect Per Milion Opportunities) untuk menentukan tingkat sigma atau nilai Sigma Level.

$$
\begin{aligned}
D P O & =\frac{\text { banyak cacat yang ditemukan }}{\text { jumlah produk yang diperiksa } \times \text { CTQ potensial }} \\
D P M O & =D P O \times 1.000 .000 \\
\text { Sigma Level } & =P\left(Z<\left[\left(\frac{1.000 .000-D P M O}{1.000 .000}\right)+1,5\right]\right) .
\end{aligned}
$$

(3) Tahap Analyze

Pada tahap ini dilakukan analisis penyebab masalah berdasarkan pada analisis data. Hasil dari analisis tersebut dapat digunakan untuk membuat solusi dalam 
melakukan pengembangan dan perubahan (improvement) terhadap proses yang diamati. Alat yang digunakan adalah diagram sebab akibat, diagram pareto, dan peta kendali (control chart). Peta kendali yang digunakan adalah peta kendali atribut yaitu peta kendali u dan peta kendali demerit.

(a) Peta Kendali $u$

Peta kendali $u$ digunakan apabila sampel yang diambil bervariasi atau memang seluruh produk yang dihasilkan akan diuji. Banyaknya kesalahan dalam satu unit produk untuk sampel berbeda adalah:

$$
u_{i}=\frac{c_{i}}{n_{i}} .
$$

Batas kendali untuk peta kendali $u$ adalah :

$$
\begin{aligned}
C L & =\bar{u}=\frac{\sum_{i=1}^{m} c_{i}}{\sum_{i=1}^{m} n_{i}}, \\
U C L_{i} & =\bar{u}+3 \sqrt{\frac{\bar{u}}{n_{i}}}, \\
L C L_{i} & =\bar{u}-3 \sqrt{\frac{\bar{u}}{n_{i}}},
\end{aligned}
$$

dimana :

$u$ : proporsi cacat setiap sampel untuk setiap pengamatan,

$c_{i}$ : banyaknya produk cacat dalam setiap unit sampel untuk masing-masing pengamatan,

$n_{i}$ : jumlah produksi pada pengamatan ke $-i$,

$m$ : banyak pengamatan dilakukan. [2]

(b) Peta Kendali Demerit

Peta kendali demerit digunakan untuk mengklasifikasikan ketidaksesuaian atau cacat sesuai dengan tingkat keparahan dan bobot berbagai jenis cacat. Pola cacat produk secara umum berdasarkan bobot cacatnya adalah sebagai berikut :

(i) Cacat kelas A (Sangat Serius), yaitu unit akan menyebabkan kegagalan yang tidak mudah untuk diperbaiki sehingga sama sekali tidak cocok untuk ditawarkan.

(ii) Cacat kelas B (Serius), yaitu unit akan meningkatkan biaya perawatan dan bisa mengalami cacat operasional kelas A sehingga mengurangi daya hidup produk.

(iii) Cacat kelas C (Cukup Serius), yaitu unit mungkin gagal dalam pelayanan atau mungkin mengurangi umur atau biaya penawaran yang meningkat atau mengalami cacat besar dalam penyelesaian, penampilan atau kualitas kerja.

(iv) Cacat kelas D (Minor), yaitu unit memiliki ketidaksempurnaan kecil dalam bentuk akhir, penampilan atau kualitas pekerjaan sehingga tidak menyebabkan kegagalan dalam pelayanan. 
Jumlah cacat terboboti untuk masing-masing pengamatan digunakan persamaan berikut :

$$
\begin{aligned}
& d_{i}=100 c i_{A}+50 c i_{B}+10 c i_{C}+c i_{D}, \\
& u_{i}=\frac{d_{i}}{n_{i}}
\end{aligned}
$$

Nilai $\bar{u}_{A}, \bar{u}_{B}, \bar{u}_{C}, \bar{u}_{D}$ menunjukkan rata-rata cacat kelas $\mathrm{A}, \mathrm{B}, \mathrm{C}$ dan $\mathrm{D}$ per unit, yaitu :

$$
\begin{aligned}
\bar{u}_{A} & =\frac{\sum_{i=1}^{m} c i_{A}}{\sum_{i=1}^{m} n_{i}}, \\
\bar{u}_{B} & =\frac{\sum_{i=1}^{m} c i_{B}}{\sum_{i=1}^{m} n_{i}}, \\
\bar{u}_{C} & =\frac{\sum_{i=1}^{m} c i_{C}}{\sum_{i=1}^{m} n_{i}}, \\
\bar{u}_{D} & =\frac{\sum_{i=1}^{m} c i_{D}}{\sum_{i=1}^{m} n_{i}}, \\
\bar{u}^{\prime} & =100 \bar{u}_{A}+50 \bar{u}_{B}+10 \bar{u}_{C}+\bar{u}_{D}, \\
\widehat{\sigma}_{u} & =\sqrt{\frac{(100)^{2} \bar{u}_{A}+(50)^{2} \bar{u}_{B}+(10)^{2} \bar{u}_{C}+\bar{u}_{D}}{n}} .
\end{aligned}
$$

Batas kendali untuk peta kendali demerit adalah :

$$
\begin{aligned}
C L & =\bar{u}, \\
U C L & =\bar{u}+3 \widehat{\sigma}_{u}, \\
L C L & =\bar{u}-3 \widehat{\sigma}_{u}
\end{aligned}
$$

dimana :

$$
\begin{aligned}
& \bar{u}_{A} \text { : Jumlah cacat kategori A pada pengamatan ke }-i, \\
& \bar{u}_{B}: \text { Jumlah cacat kategori B pada pengamatan ke }-i \\
& \bar{u}_{C}: \text { Jumlah cacat kategori C pada pengamatan ke }-i \\
& \bar{u}_{D}: \text { Jumlah cacat kategori D pada pengamatan ke }-i \\
& d_{i}: \text { Jumlah cacat terboboti pada pengamatan ke }-i \\
& u_{i}: \text { Rata-rata cacat per unit pada pengamatan ke }-i \\
& n: \text { Jumlah unit yang diperiksa } \\
& m: \text { Banyak pengamatan }[2]
\end{aligned}
$$

(4) Tahap Improve

Pada tahap ini dilakukan pengujian dari solusi yang telah didapat untuk mengeliminasi penyebab masalah yang ada dan improve proses yang ada.

(5) Tahap Control

Tahap terakhir yang dilakukan dalam peningkatan kualitas menggunakan DMAIC adalah tahap control. Tahap terakhir ini bertujuan untuk melakukan kontrol dalam setiap kegiatan, sehingga memperoleh hasil yang baik dan dapat mengurangi waktu, masalah, dan biaya yang tidak dibutuhkan. 


\section{Pembahasan}

\subsection{Tahap Define}

Dari spesifikasi standar produksi air mineral kemasan cup $240 \mathrm{ml}$ yang telah ditetapkan oleh PT. Gunung Naga Mas masih ada hasil produksi yang mengalami kecacatan atau dengan kata lain tidak memenuhi standar produksi yang telah ditetapkan. Jenis cacat yang terjadi pada produksi air mineral kemasan cup $240 \mathrm{ml}$ antara lain : air kotor/berisi benda lain, air kurang dari volume pack, lid tidak presisi/timpang, cup pp bocor, cup pp bocor sealer, cup pp rijek pemasok, dan bocor jarum.

\subsection{Tahap Measure}

(a) Menentukan karakteristik CTQ (Critical to Quality) Hasil pemeriksaan menunjukkan bahwa jenis cacat produksi air mineral kemasan cup $240 \mathrm{ml}$ antara lain : air kotor/berisi benda lain, air kurang dari volume pack, lid tidak presisi/timpang, cup pp bocor, cup pp bocor sealer, cup pp rijek pemasok, dan bocor jarum. Jadi jumlah karakteristik CTQ potensial sebanyak 7.

(b) Pengukuran baseline kinerja Dari perhitungan data diperoleh nilai DPMO sebesar 26.547 yang setara dengan sigma level $=3,49$.

\subsection{Tahap Analyze}

(1) Analisis Produk Air Mineral Kemasan cup $240 \mathrm{ml}$ Jenis-jenis cacat produk air mineral kemasan cup $240 \mathrm{ml}$ berupa :

(a) Air kotor/berisi benda lain adalah produk yang berisi benda asing.

(b) Air kurang dari volume pack adalah volume air kurang dari yang ditentukan.

(c) Lid tidak presisi/timpang adalah posisi lid tidak sesuai dengan syarat produksi.

(d) Cup pp bocor adalah cup rusak/cacat dan bocor pada bagian cup.

(e) Cup pp bocor sealer adalah rusak/cacat pada cup yang diakibatkan karena sealer (perekat) merk bermasalah.

(f) Cup pp rijek pemasok adalah cacat selain dari cacat yang lain.

(g) Bocor jarum adalah bocor pada air kemasan cup $240 \mathrm{ml}$ yang sangat kecil.

(2) Analisis Perhitungan Nilai DPMO dan Nilai Sigma Level

Pada perhitungan yang telah dilakukan didapat nilai rata-rata DPMO sebesar 26.547 dan rata-rata Sigma Level sebesar 3,49. Nilai DPMO sebesar 26.547 dapat disimpulkan bahwa dari satu juta kesempatan akan terdapat 26.547 kemungkinan bahwa proses produksi air mineral kemasan cup $240 \mathrm{ml}$ menghasilkan produk yang cacat. Nilai DPMO dan Sigma level untuk setiap pengamatan dapat dibentuk dalam bentuk grafik berikut.

Gambar 1(a) dan 1(b) menunjukkan pola DPMO (Defect per Million Opportunities) dari kecacatan produk dan Sigma Level yang belum konsisten, masih 


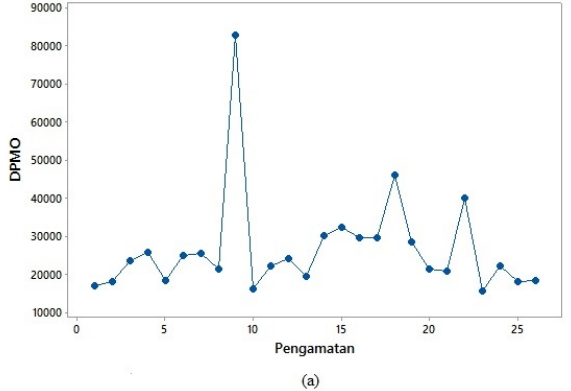

Gambar 1. (a) Pola DPMO dari Data

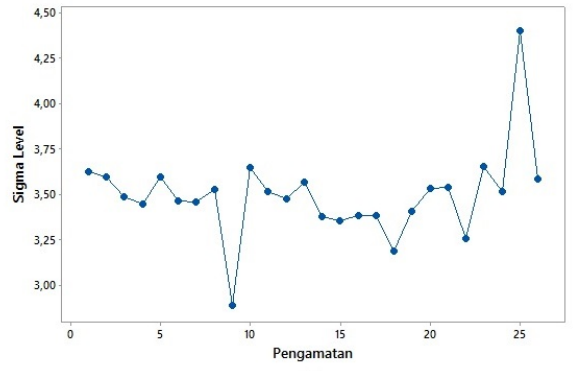

(b) Pola Sigma Level dari Data

bervariasi naik turun dan tidak teratur sekaligus juga menunjukkan bahwa proses produksi belum dikelola secara baik karena masih banyak terjadi cacat.

(3) Analisis Penyebab Potensial Cacat

(a) Diagram Pareto

Pada Gambar 2 dapat dilihat bahwa di dalam proses produksi air mineral kemasan cup $240 \mathrm{ml}$, jenis cacat yang banyak terjadi adalah cup pp rijek pemasok dengan nilai 10.857 yang memberikan kontribusi sebesar 31,8\%, air kurang dari volume pack dengan nilai 10.131 yang memberikan kontribusi sebesar 29,7\%, dan cup pp bocor dengan nilai 6.620 yang memberikan kontribusi sebesar $19,4 \%$.

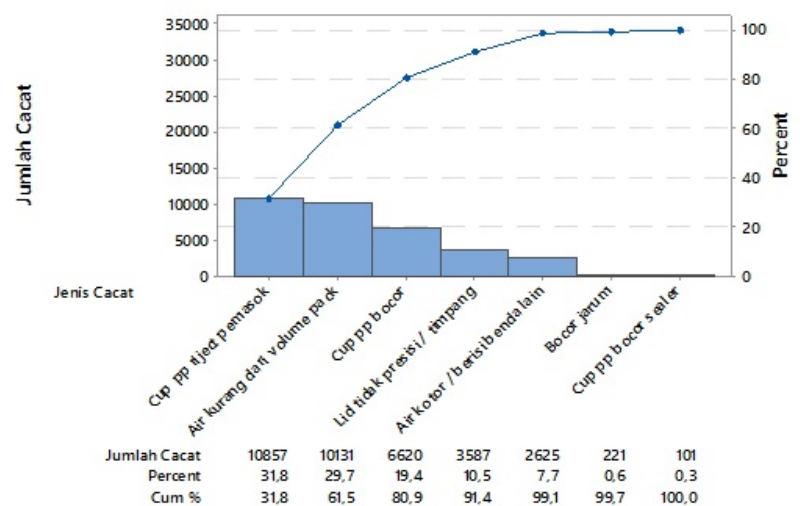

Gambar 2. Diagram Pareto Kecacatan Air Mineral Kemasan Cup 240 ml

(b) Diagram Sebab-Akibat

Adapun penyebab dari cacat-cacat yang terjadi pada produksi air mineral kemasan cup $240 \mathrm{ml}$ dapat dipengaruhi oleh manusia selaku yang memproduksi (operator/karyawan), lingkungan yang harus dijaga kebersihan dan kenyamanannya, material sebagai bahan baku yaitu air, mesin sebagai alat 
utama untuk produksi, dan metode sebagai urutan proses memproduksi air mineral kemasan cup $240 \mathrm{ml}$. Diagram sebab-akibat cacat paling dominan dapat dilihat pada Gambar 3, Gambar 4 dan Gambar 5.

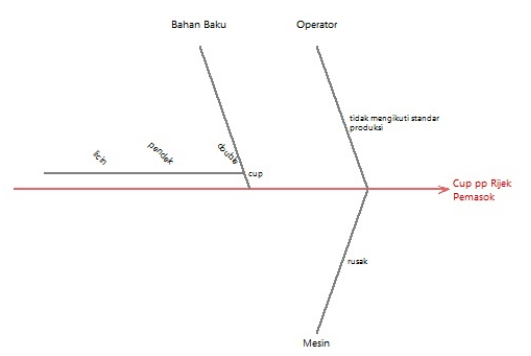

Gambar 3. Diagram Sebab Akibat Cacat Cup PP Rijek Pemasok

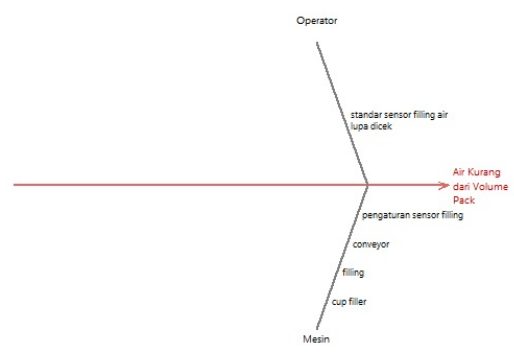

Gambar 4. Diagram Sebab Akibat Cacat Air Kurang dari Volume Pack

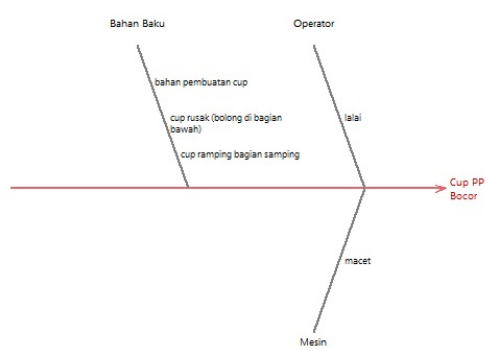

Gambar 5. Diagram Sebab Akibat Cacat Cup PP Bocor

(c) Peta Kendali u 


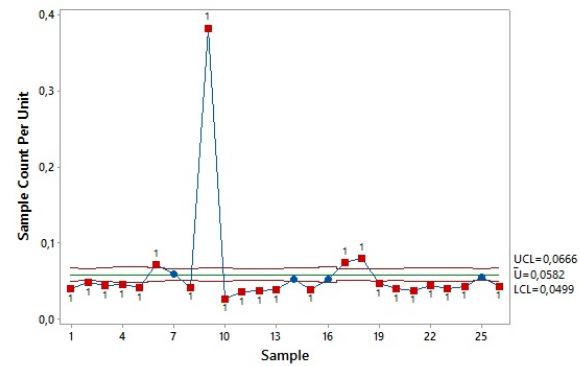

Gambar 6. Peta Kendali U Cup PP Rijek Pemasok

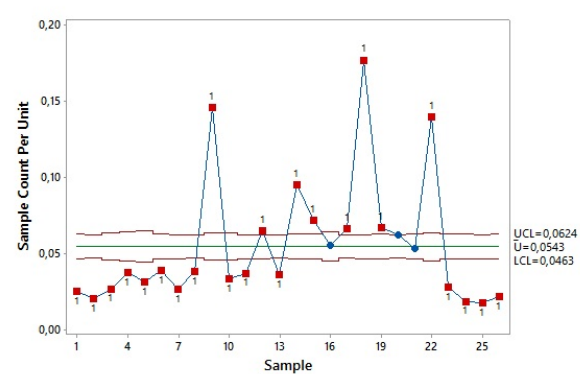

Gambar 7. Peta Kendali U Air Kurang dari Volume Pack

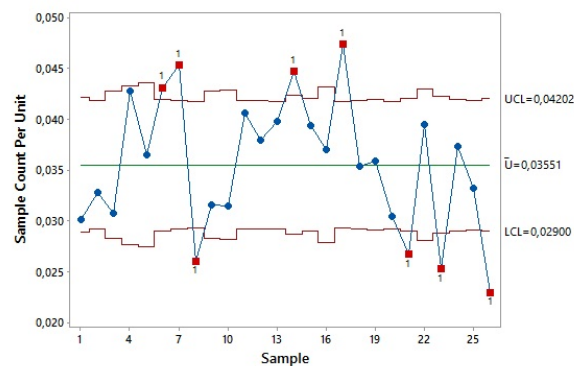

Gambar 8. Peta Kendali U Cup PP Bocor

Dari Gambar 6, Gambar 7 dan Gambar 8 terlihat bahwa cacat cup pp rijek pemasok, air kurang dari volume pack, dan cup pp bocor tidak terkendali.

(d) Peta Kendali Demerit

Terlihat dari Gambar 9 bahwa dari 26 data hanya satu data yang berada di dalam batas kendali sehingga disimpulkan bahwa peta kendali demerit tidak terkendali. 


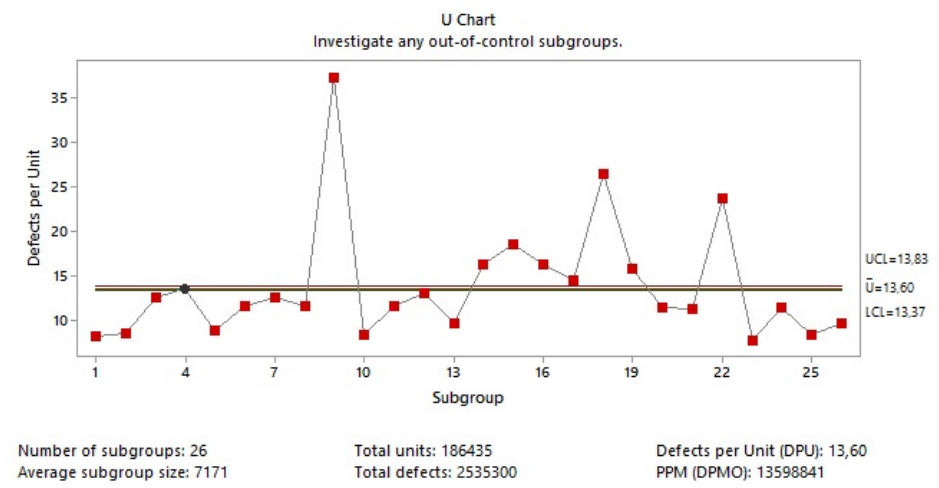

Gambar 9. Peta Kendali Demerit

\subsection{Tahap Improve}

Pada tahap ini dilakukan perbaikan terhadap penyebab-penyebab cacat pada produk air mineral kemasan cup $240 \mathrm{ml}$. Memperhatikan proses produksi, perbaikan mesin, pengawasan yang lebih ketat terhadap operator yang bertugas dan penyesuaian bahan yang digunakan dengan standar produksi perusahaan.

\subsection{Tahap Control}

Tahap Control merupakan tahap terakhir dari metodologi program Six Sigma. Tahap control tidak dapat dilakukan oleh peneliti, karena pengontrolan ini merupakan wewenang dari pihak perusahaan dan tahap control ini dilakukan dalam waktu yang lama karena harus dilakukan terus menerus, sementara peneliti memiliki waktu yang singkat.

\section{Kesimpulan}

Berdasarkan hasil yang telah didapatkan pada pembahasan sebelumnya maka dapat disimpulkan bahwa:

(1) Karakteristik kualitas atau Critical to Quality (CTQ) untuk produksi air mineral kemasan cup $240 \mathrm{ml}$ ada 7 macam. Setelah dilakukan pengolahan data diketahui persentase tiap jenis CTQ produksi air minum cup $240 \mathrm{ml}$ (dari Gambar 3) yaitu cup pp rijek pemasok (31,8\%), air kurang dari volume pack $(29,7 \%)$, cup pp bocor $(19,4 \%)$, lid tidak presisi/timpang (10,5\%), air kotor/berisi benda lain $(7,7 \%)$, bocor jarum $(0,6 \%)$ dan cup pp bocor sealer $(0,3 \%)$ dengan total jumlah cacat 34142 .

(2) Dari perhitungan diperoleh rata-rata nilai baseline kinerja yaitu rata-rata DPMO sebesar 26.547 yang setara dengan rata-rata Sigma Level sebesar 3,49. Artinya, bahwa dari satu juta kesempatan yang ada akan terdapat 26.547 kemungkinan bahwa proses produksi air mineral kemasan cup $240 \mathrm{ml}$ tidak sesuai dengan spesifikasi atau standar produksi yang ditetapkan perusahaan. 
102 Karina Foresti dkk.

(3) Klasifikasi jenis cacat dibagi menjadi dua yaitu: Sangat serius (A) antara lain air kotor/berisi benda lain, air kurang dari volume $p a c k$, lid tidak presisi/timpang dan bocor jarum. Serius (B) antara lain cup pp bocor, cup pp bocor sealer dan cup pp rijek pemasok.

(4) Dari peta kendali $u$ percacat dapat disimpulkan bahwa hanya cacat bocor jarum yang berada dalam kendali statistik (terkendali) sedangkan cacat lainnya tidak terkendali. Dari peta kendali $u$ demerit terlihat bahwa dari 26 data hanya satu data yang berada di dalam batas kendali sehingga disimpulkan bahwa peta kendali demerit tidak terkendali.

\section{Daftar Pustaka}

[1] Larasati, N.D dan Aridinanti, L. 2016. Pengendalian Kualitas Proses Produksi Kaca Lembaran Jenis Laminated di PT. X dengan Metode Six Sigma. Jurnal Sains dan Seni ITS. 5(1): $15-16$.

[2] Montgomery, D. C. 2009. Introduction to Statistical Process Control Sixth Edition. International Student Version. Arizona.

[3] PT. Citra Cendekia Indonesia (CCI). 2017. Perkembangan Produksi Air Minum Dalam Kemasan (AMDK) 